\title{
Degradation of Surface Passivation on Crystalline Silicon and Its Impact on Light-Induced Degradation Experiments
}

\author{
David Sperber ${ }^{\circledR}$, Alexander Graf, Daniel Skorka, Axel Herguth, and Giso Hahn
}

\begin{abstract}
A decrease of surface passivation quality is observed in $\mathrm{FZ}, \mathrm{Cz}$, and mc-Si lifetime samples during light-induced degradation (LID) treatments. It is shown that this degradation occurs not only in samples with single $\mathrm{SiN}_{\mathrm{x}}: \mathrm{H}$ layers but also when using layer stacks consisting of $\mathrm{SiO}_{\mathrm{x}} / \mathrm{SiN}_{\mathrm{x}}: \mathrm{H}$ or $\mathrm{AlO}_{\mathrm{x}}: \mathrm{H} / \mathrm{SiN}_{\mathrm{x}}: \mathrm{H}$. Timeresolved calculation of the surface saturation current density $J_{0 \mathrm{~s}}$ is shown to be a reliable method to separate changes in the bulk and at the surface of samples during LID treatments. The impact of the observed changes in passivation quality on the outcome and interpretation of LID experiments aiming at changes in the bulk of $\mathrm{Cz}$ or $\mathrm{mc}-\mathrm{Si}$ is investigated and discussed.
\end{abstract}

Index Terms-Aluminum oxide, charge carrier lifetime, crystalline silicon, degradation, float-zone, silicon nitride, silicon oxide, silicon photovoltaics, stability, surface passivation.

\section{INTRODUCTION}

$\mathbf{L}$ IGHT-INDUCED degradation (LID) [1] such as boronoxygen (BO) related degradation in Czochralski silicon (Cz-Si) [2]-[4] or LID in multicrystalline silicon (mc-Si) [5][7] can severely reduce bulk minority charge carrier lifetime $\tau_{b}$ in crystalline silicon and thereby limit the efficiency of solar cells, especially if the concept relies on high $\tau_{b}$ like a passivated emitter and rear cell (PERC) concept [8]. However, both types of LID can be followed by subsequent regeneration of $\tau_{b}$ [9][12] allowing for permanent curing of LID in the bulk. Once $\tau_{b}$ is sufficiently high, surface passivation becomes the limiting factor and renders solar cells more susceptible to degradation of surface passivation.

In LID experiments on lifetime samples, it has already been shown that, indeed, passivation quality of $\mathrm{SiN}_{\mathrm{x}}: \mathrm{H}$ layers or stacks thereof changes in the course of time [13]-[15]. However, interpretation of measurement data can be quite tricky as bulk and surface-related recombination (and changes thereof) both determine the measured effective lifetime $\tau_{\text {eff }}$.

In this study, we investigate changes in surface passivation during LID treatments of lifetime samples made of different
Si materials. First, it will be shown that a time- and injectionresolved visualization of lifetime data and a time-resolved calculation of the surface saturation current density $J_{0 s}$ [16] are useful tools for assessing the degree of degradation in surface passivation, even in the case of changes of $\tau_{b}$ during an ongoing treatment. This method is then applied to compare different passivation layers with regard to severity and timescale of surface-related degradation. Subsequently, a Cz-Si and a mc$\mathrm{Si}$ sample are presented to investigate the impact of changes in surface passivation quality on long-term LID experiments aimed at observing changes in the silicon bulk. Finally, possible surface-related degradation mechanisms are discussed.

\section{EXPERIMENTAL}

\section{A. Sample Preparation}

Samples were made of either B-doped float-zone silicon (FZ$\mathrm{Si}$, $\mathrm{Cz}-\mathrm{Si}$, or mc-Si, or P-doped FZ-Si. Because a wide variety of processing parameters was used, standard processing is described here and deviations of this process as well as sample thickness are described in the figure captions.

For most samples, material with a specific resistivity $\rho \approx$ $2 \Omega \cdot \mathrm{cm}$ was used. $\mathrm{Cz}-\mathrm{Si}, \mathrm{mc}-\mathrm{Si}$, and selected $\mathrm{FZ}-\mathrm{Si}$ samples first received a saw damage etch in $\mathrm{KOH}$ at $80^{\circ} \mathrm{C}$, followed by a chemical polish (CP) etch in a solution of nitric acid, acetic acid, and hydrofluoric acid (HF) at room temperature. All but selected FZ-Si samples were then wet-chemically oxidized in a solution of $\mathrm{H}_{2} \mathrm{O}_{2}$ and $\mathrm{H}_{2} \mathrm{SO}_{4}$ at $80{ }^{\circ} \mathrm{C}$, followed by a dip in $\mathrm{HF}$ to remove impurities from the sample surface (Piranha clean).

Samples with single $\mathrm{SiN}_{\mathrm{x}}: \mathrm{H}$ layers were coated on both sides in an industrial direct plasma-enhanced chemical vapor deposition (PECVD) with a frequency of $40 \mathrm{kHz}$. Samples with a $\mathrm{SiO}_{\mathrm{x}} / \mathrm{SiN}_{\mathrm{x}}: \mathrm{H}$ stack first received $\sim 10 \mathrm{~nm} \mathrm{SiO}_{\mathrm{x}}$ in a thermal oxidation at $900{ }^{\circ} \mathrm{C}$ before deposition of $\mathrm{SiN}_{\mathrm{x}}: \mathrm{H}$ in a laboratory direct plasma PECVD at $13.56 \mathrm{MHz}$. Samples passivated with $\mathrm{AlO}_{\mathrm{x}}: \mathrm{H} / \mathrm{SiN}_{\mathrm{x}}: \mathrm{H}$ received $\sim 10 \mathrm{~nm}$ of atomic layer deposited $\mathrm{AlO}_{\mathrm{x}}: \mathrm{H}$ (refractive index $n \approx 1.7$ at $600 \mathrm{~nm}$ ) followed by $\mathrm{SiN}_{\mathrm{x}}: \mathrm{H}$ deposition in an industrial remote plasma PECVD at $2.45 \mathrm{GHz}$. All $\mathrm{SiN}_{\mathrm{x}}: \mathrm{H}$ layers had a thickness of $\sim 75 \mathrm{~nm}$ and $n \approx 2.0$ at $600 \mathrm{~nm}$.

Afterwards, samples were fired in a fast firing belt furnace. Temperature profiles were tracked on selected samples with a thin type $\mathrm{K}$ thermocouple contacting the upper side of a sample by mechanical prestrain, thereby not changing sample properties significantly. The mc-Si sample was fired at a measured peak 

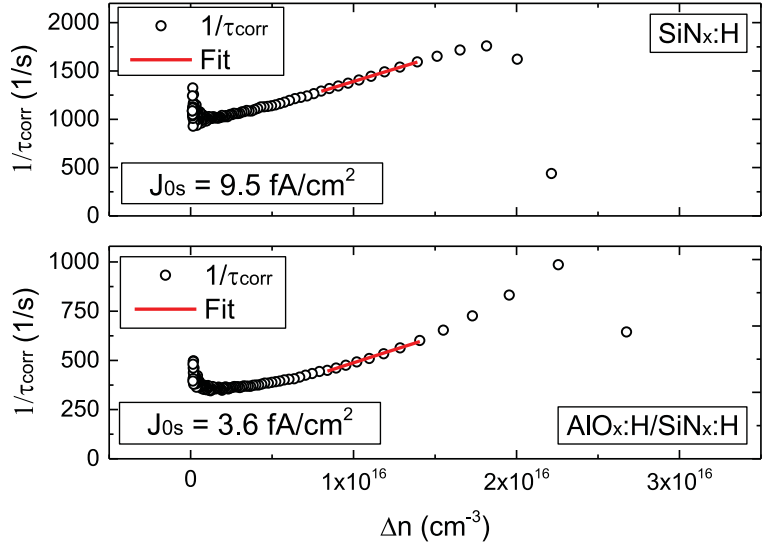

Fig. 1. (Top) Inverse corrected lifetime data $1 / \tau_{\text {corr }}$ and $J_{0 s}$ fit of a B-doped FZ-Si sample $(\sim 1 \Omega \cdot \mathrm{cm}, 250 \mu \mathrm{m})$ passivated with $\mathrm{SiN}_{\mathrm{x}}: \mathrm{H}$. (Bottom) $1 / \tau_{\text {corr }}$ and $J_{0 s}$ fit of a B-doped FZ-Si sample $(\sim 2 \Omega \cdot \mathrm{cm}, \sim 180 \mu \mathrm{m})$ passivated with $\mathrm{AlO}_{\mathrm{x}}: \mathrm{H} / \mathrm{SiN}_{\mathrm{x}}: \mathrm{H}$. Measurements were taken before LID treatments started.

sample temperature of $\sim 730{ }^{\circ} \mathrm{C} . \mathrm{AlO}_{\mathrm{x}}: \mathrm{H} / \mathrm{SiN}_{\mathrm{x}}: \mathrm{H}$ passivated samples were fired at $\sim 750{ }^{\circ} \mathrm{C}$. All other samples were fired at $\sim 800^{\circ} \mathrm{C}$. After firing, samples were stored in darkness at room temperature until LID treatments started.

\section{B. LID Treatments and Measurement Techniques}

Samples were treated at $\sim 1$ sun equivalent illumination intensity at elevated temperatures ranging from $80{ }^{\circ} \mathrm{C}$ to $150{ }^{\circ} \mathrm{C}$. Illumination was achieved with halogen incandescent lamps and illumination intensity was measured using a solar cell. One sun equivalent illumination was achieved by matching the shortcircuit current $j_{\mathrm{sc}}$ of the measurement cell under the treatment illumination to that under a solar spectrum simulator (see [17] for further discussion of the unit "sun equivalent").

To measure $\tau_{\text {eff }}$, samples were repeatedly taken from a treatment hotplate, and a photoconductance decay (PCD) measurement was carried out at $30^{\circ} \mathrm{C}$ using the generalized mode of a Sinton Instruments lifetime tester (WCT-120). In most graphs, $\tau_{\text {eff }}$ is shown at an injection $\Delta n \approx 0.1 N_{d}$, with $N_{d}$ being the doping density. Injection-resolved graphs, on the other hand, feature a color-coded range of $\tau_{\text {eff }}$ at different $\Delta n$.

To quantify recombination at the surface, we apply the approach for determination of the emitter saturation current density $J_{0 e}$ as described by Kimmerle et al. [18]: First, inverse corrected lifetime data $1 / \tau_{\text {corr }}$ are calculated which take into account bandgap narrowing [19], [20], a potential ShockleyRead-Hall recombination in the bulk [21], [22], and a diffusion correction which may be necessary at higher injection. We use this approach on samples without emitter, and a linear fit of $1 / \tau_{\text {corr }}$, therefore, yields the surface saturation current density $J_{0 s}[16]$ as shown in two examples in Fig. 1.

The range of $\Delta n$ for the fit of $J_{0 s}$ is set from $8 \cdot 10^{15}$ to $1.5 \cdot 10^{16} \mathrm{~cm}^{-3}$ with the exception of one $200 \Omega \cdot \mathrm{cm}$ sample where $\Delta n$ ranges from $5 \cdot 10^{15}$ to $8 \cdot 10^{15} \mathrm{~cm}^{-3}$ due to a limited injection range of PCD measurement data. The upper limit makes sure that measurement artifacts at the beginning of a PCD measurement (equaling highest $\Delta n$ ) do not influence the $J_{0 s}$ fit while the overall restriction to measurement data to rather high
$\Delta n$ further reduces influences of changes in $\tau_{b}$ on the determination of $J_{0 s}$.

While the linear fit is of good quality in most cases (Fig. 1, top), samples with very low $J_{0 s}<5 \mathrm{fA} / \mathrm{cm}^{2}$ show a slight bow in $1 / \tau_{\text {corr }}$ data used for the fit of $J_{0 s}$ (Fig. 1, bottom). Comparing different fit ranges between $\Delta n=5 \cdot 10^{15}$ and $1.5 \cdot 10^{16} \mathrm{~cm}^{-3}$ results in an estimated uncertainty of the absolute value of $J_{0 s}$ of $\sim 20 \%$, increasing up to $\sim 50 \%$ when $J_{0 s}<5 \mathrm{fA} / \mathrm{cm}^{2}$. However, as will be shown later, relative changes of $J_{0 s}$ during sample treatment exceed this uncertainty by far, making relative changes in $J_{0 s}$ well visible.

Time-resolved photoluminescence imaging (TR-PLI) [23], [24] was used for mc-Si samples instead of PCD. This offers the advantage of self-calibrated spatially resolved measurement data of $\tau_{\text {eff }}$, however, without covering the broad range of $\Delta n$ values of a PCD measurement.

\section{Superacid Repassivation of Sample Surfaces}

Dielectric passivation layers were removed from some samples after LID treatment, and samples were repassivated to gain further information about the cause of degradation.

The removal of dielectrics was accomplished by immersing samples in $\sim 10 \% \mathrm{HF}$. Afterwards, samples received a CP etch for $2 \mathrm{~min}$, removing $\sim 1 \mu \mathrm{m}$ per side. This was followed by a Piranha clean as described before. Directly before repassivation, samples were again etched in $25 \%$ tetramethylammonium hydroxide for $10 \mathrm{~min}$ at $\sim 80{ }^{\circ} \mathrm{C}$ to remove $\sim 5 \mu \mathrm{m}$ on each side. In the next step, samples were dipped in $1 \% \mathrm{HF}$ before they received a clean in a solution of $\mathrm{H}_{2} \mathrm{O}, \mathrm{H}_{2} \mathrm{O}_{2}$, and $\mathrm{HCl}$ for 10 min at $\sim 75^{\circ} \mathrm{C}$. After another dip in $2 \% \mathrm{HF}$, samples were immersed in a nonaqueous solution of bis(trifluoromethane)sulfonimide dissolved in dichloroethane $(2 \mathrm{mg} / \mathrm{ml})$ for $\sim 60 \mathrm{~s}$. This procedure leads to very good passivation of sample surfaces as described in [25] and [26] while only subjecting a sample to moderate temperatures, therefore leaving its defect properties rather unchanged. Calculating values of $J_{0 s}$ after repassivation as described in the previous section results in values $\sim 2 \mathrm{fA} / \mathrm{cm}^{2}$ on a P-doped sample and values ranging from 5 to $12 \mathrm{fA} / \mathrm{cm}^{2}$ on B-doped samples in this study.

\section{RESULTS}

\section{A. Changes in B-Doped FZ Samples Passivated With $\operatorname{SiN}_{\mathrm{x}}: H$}

Part of the data discussed in this section have already been presented in [15] and [27]. They are shown again to assess the quality of $J_{0 s}$ values and to introduce methods that will be used on other samples in subsequent sections.

Already at $80{ }^{\circ} \mathrm{C}$ and $\sim 1$ sun equivalent illumination, a B-doped FZ-Si sample passivated with $\mathrm{SiN}_{\mathrm{x}}: \mathrm{H}$ shows strong changes in $\tau_{\text {eff }}$ (Fig. 2, black data). Because FZ-Si is lean in impurities and oxygen, one could easily assume that all of these changes occur due to changes in passivation quality. However, a closer examination using corona charging series (CC, green data) and capacitance voltage measurements (blue data) on identically processed samples reveals that neither chemical passivation quality nor fixed charge density $Q_{f}$ change significantly in the short term $(<10 \mathrm{~h})$. A closer investigation in [15] and [28], including repassivation of sample surfaces, leads to the 

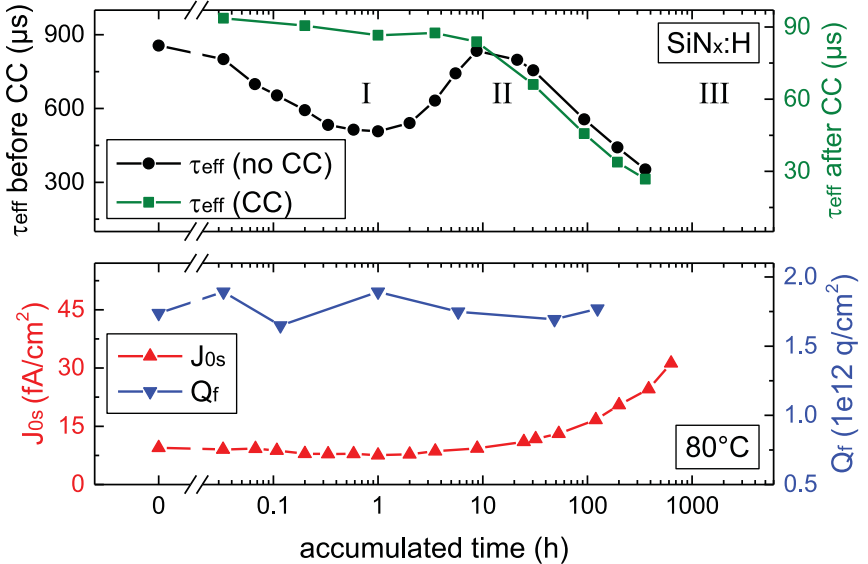

Fig. 2. (Top) PCD measurement of $\tau_{\text {eff }}$ before and after depositing corona charges (CC) on a sample treated at $80{ }^{\circ} \mathrm{C}$ and $\sim 1$ sun equivalent illumination. The B-doped FZ-Si sample $(\sim 1 \Omega \cdot \mathrm{cm}, 250 \mu \mathrm{m})$ was passivated with $\mathrm{SiN}_{\mathrm{X}}: \mathrm{H}$ (Bottom) Evaluation of $J_{0 s}$ and $Q_{f}$ of two other identically processed and treated samples. All data except $J_{0 s}$ values are taken from [15].

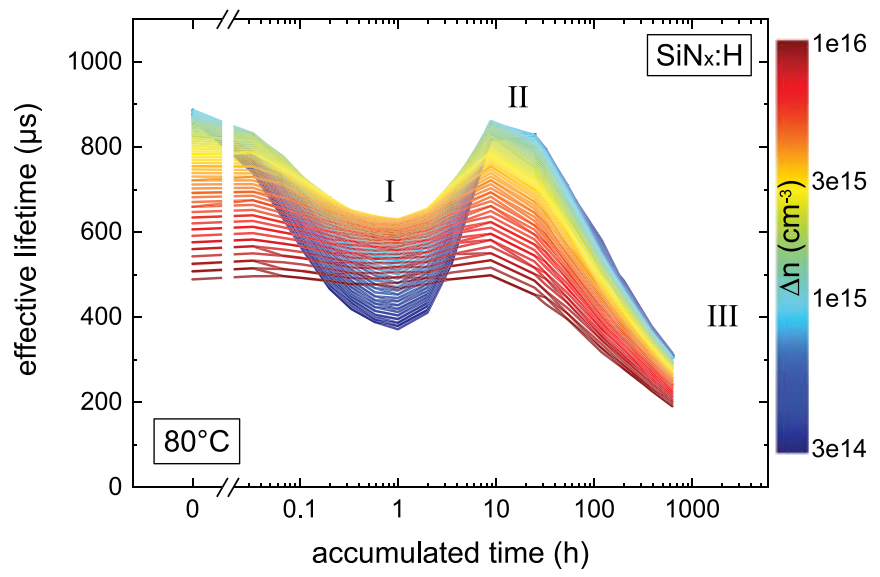

Fig. 3. Injection-resolved evolution of $\tau_{\text {eff }}$ during LID treatment at $80{ }^{\circ} \mathrm{C}$ and $\sim 1$ sun equivalent illumination of the B-doped FZ-Si sample used for the determination of $J_{0 s}$ in Fig. 2. Injection levels are color-coded, ranging from $\Delta n=3 \cdot 10^{14} \mathrm{~cm}^{-3}$ (blue) to $\Delta n=1 \cdot 10^{16} \mathrm{~cm}^{-3}$ (red). Data taken from [27].

conclusion that the first minimum and maximum in $\tau_{\text {eff }}$ (denoted with roman numbers I and II in Fig. 2) are actually caused by a degradation and regeneration of $\tau_{b}$.

For longer treatment times $(>10 \mathrm{~h})$, the renewed decrease of $\tau_{\text {eff }}$ is, however, surface related: the chemical passivation quality of the sample decreases as can be seen in the CC state of the sample with minimum field effect passivation (green data, note the different scaling), leading to a significant decrease in $\tau_{\text {eff }}$ as well. This decrease of surface passivation quality has been verified by wet-chemical repassivation of the sample surface in [15] and is correlated with increasing $J_{0 s}$ values (Fig. 2, red data). As can be seen, $J_{0 s}$ reflects changes at the surface pretty well and changes only little during changes of $\tau_{b}$ in the first hours of treatment. The changes in the bulk and at the surface are also revealed in an injection-dependent visualization of lifetime data as introduced in [25] and shown in Fig. 3. Here, it can be clearly seen that degradation and regeneration (I) of $\tau_{b}$ are especially
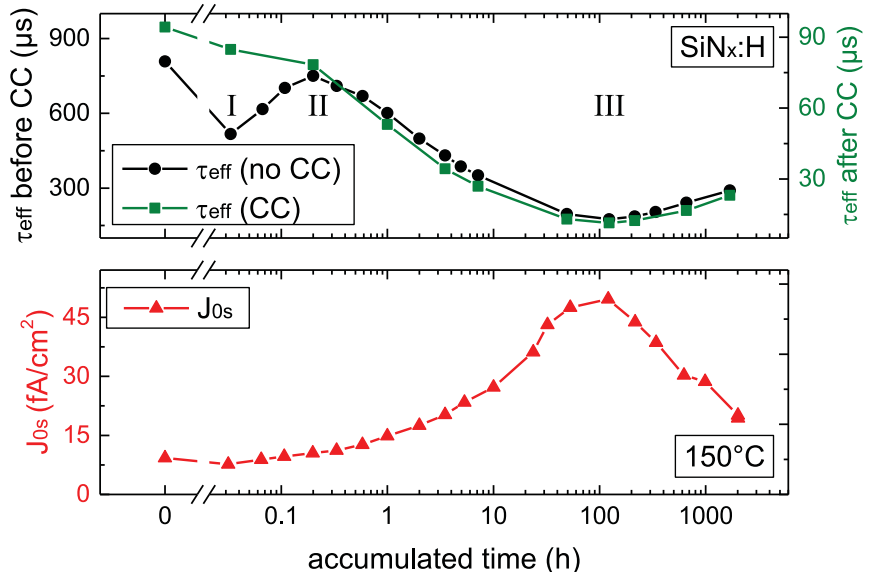

Fig. 4. (Top) Measurement of $\tau_{\text {eff }}$ before and after depositing corona charges on a B-doped FZ-Si sample treated at $150^{\circ} \mathrm{C}$ and $\sim 1$ sun equivalent illumination. The sample was processed in the same way as the ones shown in Fig. 2. (Bottom) Evaluation of $J_{0 s}$ of an identically processed and treated sample. All data except $J_{0 s}$ values are taken from [15].

pronounced at low injection (blue data) as would be expected from a deep level defect. The degradation of surface passivation (III), on the other hand, shows an inverted injection dependence with lifetime values decreasing over the whole injection range. This is in good agreement with the increasing $J_{0 s}$ values shown in Fig. 2 which arise due to a stronger limitation of $\tau_{\text {eff }}$ with increasing $\Delta n$.

Increasing the treatment temperature to $150{ }^{\circ} \mathrm{C}$ leads to an accelerated sample evolution as can be seen in Fig. 4 . The degradation of chemical passivation quality reaches a minimum III after $\sim 100 \mathrm{~h}$ of treatment time, and afterwards a recovery of chemical passivation quality sets in. At $250{ }^{\circ} \mathrm{C}, \tau_{\text {eff }}$ even recovers to values higher than the initial $\tau_{\text {eff }}[15]$.

\section{B. Degradation of $\mathrm{SiO}_{\mathrm{x}} / \mathrm{SiN}_{\mathrm{x}}:$ H Passivation Layers}

So far, samples were passivated with $\mathrm{SiN}_{\mathrm{x}}: \mathrm{H}$ only which leads to the question whether the surface-related degradation can be avoided by using other passivation layers. Fig. 5 shows a Bdoped FZ-Si sample $(\sim 2 \Omega \cdot \mathrm{cm})$ passivated with a $\mathrm{SiO}_{\mathrm{x}} / \mathrm{SiN}_{\mathrm{x}}: \mathrm{H}$ stack. Already after short illumination, a strong increase in $\tau_{\text {eff }}$ can be observed. Additionally, $J_{0 s}$ does not change significantly in the first minutes of treatment and a crossover in injection-resolved measurement data can be observed at $\Delta n \approx 1 \cdot 10^{14} \mathrm{~cm}^{-3}$ (data not shown). Therefore, it is assumed that this sample suffers to some degree from iron contamination, resulting in FeB dissociation and increased $\tau_{\text {eff }}$ after short illumination [29]. For longer treatment times, however, a strong degradation of $\tau_{\text {eff }}$ can be seen and the increasing $J_{0 s}$ indicates that this degradation is related to the surface of the sample, similar to the $\mathrm{SiN}_{\mathrm{X}}: \mathrm{H}$ samples discussed before. Wet chemical repassivation of the sample after treatment confirms this finding: $\tau_{\text {eff }}$ increases from $\sim 140 \mu$ s to $\sim 1.5 \mathrm{~ms}\left(\Delta n \approx 0.1 \mathrm{~N}_{d}\right)$, proving that $\tau_{b}$ is still very high.

The injection-resolved visualization of measurement data shown in Fig. 6 additionally reveals that this sample suffers from a slight degradation at low injection (blue) during the first hours of treatment, leading to the shoulder in Fig. 5 at around $\sim 10 \mathrm{~h}$. 


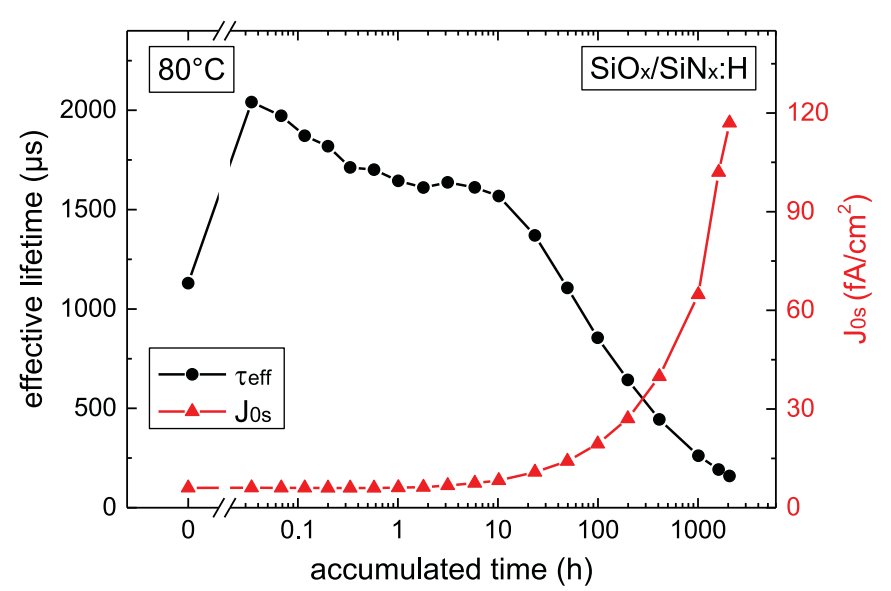

Fig. 5. Measurement of $\tau_{\text {eff }}$ (black) and $J_{0 s}$ (red) of a B-doped FZ-Si sample $(\sim 2 \Omega \cdot \mathrm{cm}, 250 \mu \mathrm{m})$ passivated with $\mathrm{SiO}_{\mathrm{x}} / \mathrm{SiN}_{\mathrm{x}}: \mathrm{H}$ and treated at $80{ }^{\circ} \mathrm{C}$ and $\sim 1$ sun equivalent illumination. Instead of wet-chemical cleaning, the sample received only a dip in HF before thermal oxidation.

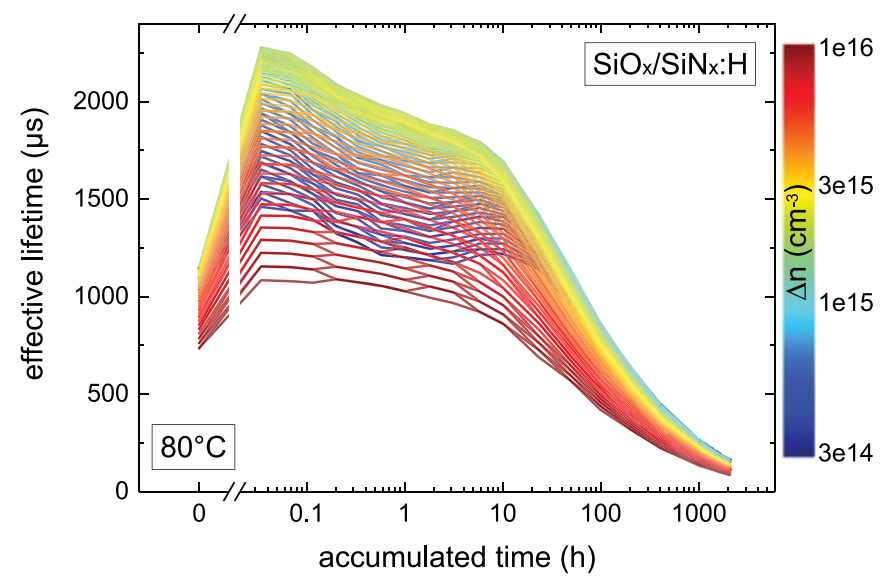

Fig. 6. Injection-resolved evolution of $\tau_{\text {eff }}$ of the B-doped FZ-Si sample shown in Fig. 5.

This is probably related to the bulk degradation described in Section III-A. It is noteworthy that FZ-Si bulk degradation appears to be much weaker in a $\mathrm{SiO}_{\mathrm{x}} / \mathrm{SiN}_{\mathrm{x}}: \mathrm{H}$ passivated sample compared to a $\mathrm{SiN}_{\mathrm{x}}: \mathrm{H}$ passivated sample. However, the bulk degradation is not the scope of the current study and ongoing experiments aim at clarifying where the difference in bulk degradation originates from.

As was already observed in [27], degradation in surface passivation quality also affects $\mathrm{P}$-doped samples with $\mathrm{SiN}_{\mathrm{x}}: \mathrm{H}$ passivation. To compare the surface-related degradation of $\mathrm{SiO}_{\mathrm{x}} / \mathrm{SiN}_{\mathrm{x}}: \mathrm{H}$ passivated samples made of different base materials, their $J_{0 s}$ values are shown in Fig. 7. While all samples are affected by degradation in surface passivation quality, it seems that the degradation progresses slower or less pronounced on the lightly B-doped and P-doped samples. Wet chemical repassivation of the P-doped sample after treatment leads to an increase from $\sim 810 \mu$ s to $\sim 4.5 \mathrm{~ms}$, confirming a significant surfacerelated degradation.

Additionally, a recovery of surface passivation quality has been observed in $\mathrm{SiO}_{\mathrm{x}} / \mathrm{SiN}_{\mathrm{x}}: \mathrm{H}$ passivated samples at higher

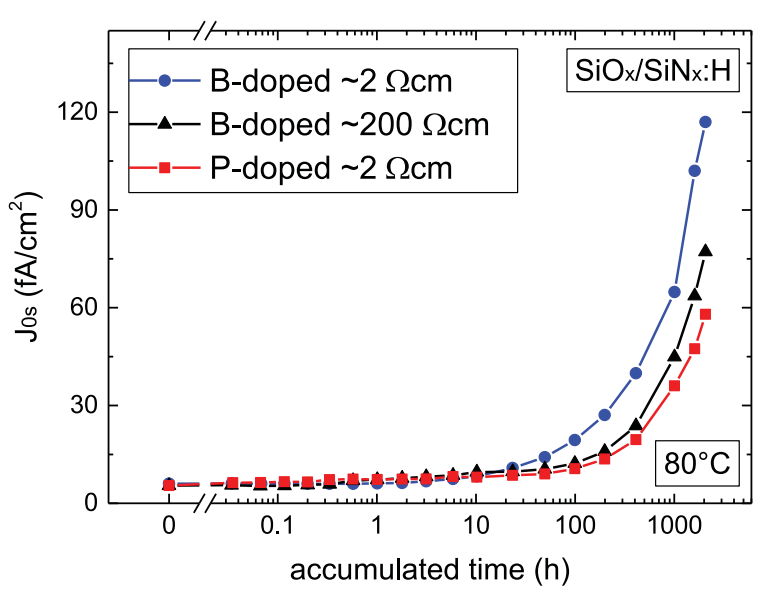

Fig. 7. Evolution of $J_{0 s}$ of samples made of different FZ-Si base material and treated at $80^{\circ} \mathrm{C}$ and $\sim 1$ sun equivalent illumination. All samples (thickness $250 \mu \mathrm{m}$ ) were processed identically and passivated with $\mathrm{SiO}_{\mathrm{x}} / \mathrm{SiN}_{\mathrm{X}}: \mathrm{H}$. Instead of wet-chemical cleaning, the samples received only a dip in HF before thermal oxidation.

treatment temperatures, similar to the $\mathrm{SiN}_{\mathrm{x}}: \mathrm{H}$ sample shown in Fig. 4 (data not shown).

\section{Degradation of $A l O_{\mathrm{x}}: H / \mathrm{SiN}_{\mathrm{x}}: H$ Passivation Layers}

Passivating a B-doped FZ-Si sample with $\mathrm{AlO}_{\mathrm{x}}: \mathrm{H} / \mathrm{SiN}_{\mathrm{x}}: \mathrm{H}$ may lead to a surface-related degradation, too, as can be seen in Figs. 8 and 9. The sample first underwent an LID treatment at $150{ }^{\circ} \mathrm{C}$ and $\sim 1$ sun equivalent illumination for $12 \mathrm{~min}$ because it served as a reference for BO-regenerated $\mathrm{Cz}-\mathrm{Si}$ samples. It was then treated at $80{ }^{\circ} \mathrm{C}$ and $\sim 1$ sun equivalent illumination. The sample first shows a slight degradation and regeneration of $\tau_{\text {eff }}$ during the first hours of treatment. These changes are most pronounced at low injection (Fig. 9, blue data) and probably related to changes in the FZ-Si bulk as already described before. It seems likely that the initial treatment at $150{ }^{\circ} \mathrm{C}$ was too short to fully regenerate the FZ-Si bulk and therefore, some degradation and regeneration still occur after the initial LID treatment at higher temperature.

After treatment times $>100 \mathrm{~h}$, surface-related degradation sets in according to rising $J_{0 s}$ values. Wet chemical repassivation after LID treatment leads to an increase of $\tau_{\text {eff }}$ from $\sim 0.9$ to $\sim 1.1 \mathrm{~ms}\left(\Delta n \approx 0.1 \mathrm{~N}_{d}\right)$. The $J_{0 s}$ value after repassivation was, however, comparably high $\left(\sim 12\right.$ versus $\sim 5 \mathrm{fA} / \mathrm{cm}^{2}$ in other repassivated samples) and therefore only slightly lower compared to the already degraded $J_{0 s}$ value of the sample before repassivation $\left(\sim 15 \mathrm{fA} / \mathrm{cm}^{2}\right)$. This explains the rather low difference between the value before and after repassivation.

Compared to $\mathrm{SiN}_{\mathrm{x}}: \mathrm{H}$ and $\mathrm{SiO}_{\mathrm{x}} / \mathrm{SiN}_{\mathrm{x}}: \mathrm{H}$ samples, the degradation occurs at a later point in time. Similarly processed $\mathrm{AlO}_{\mathrm{x}}: \mathrm{H} / \mathrm{SiN}_{\mathrm{x}}: \mathrm{H}$ passivated $\mathrm{Cz}-\mathrm{Si}$ samples degrade on a similar timescale but less strongly compared to the FZ-Si sample (data not shown). It might be possible that the FZ-Si sample shown in Fig. 8 received an atypical dielectric deposition (optically inhomogeneous sample surface) and therefore suffers from stronger degradation. However, it can be stated that even an $\mathrm{AlO}_{\mathrm{x}}: \mathrm{H} / \mathrm{SiN}_{\mathrm{x}}: \mathrm{H}$ passivated sample may degrade significantly. Similar to the samples discussed before, a recovery of passi- 


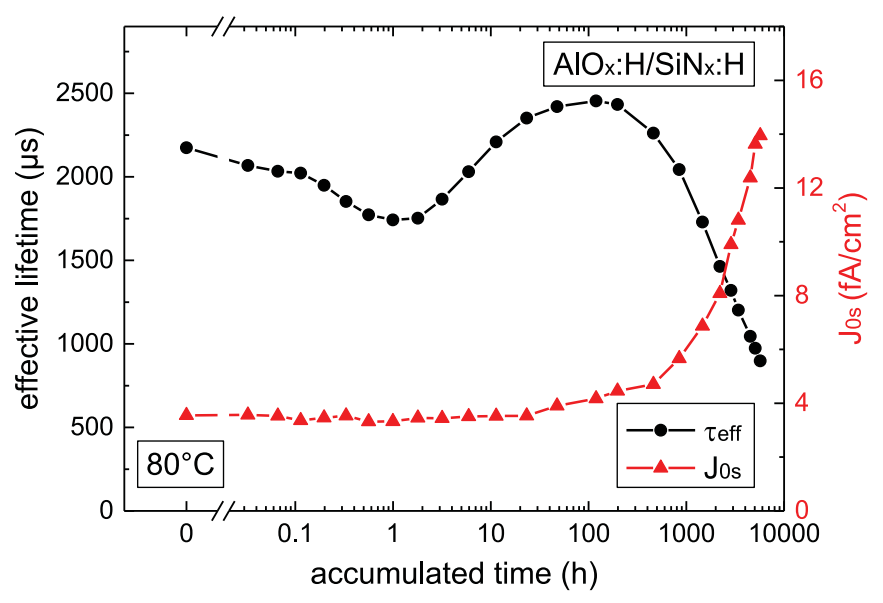

Fig. 8. Measurement of $\tau_{\text {eff }}$ (black) and $J_{0 s}$ (red) of a B-doped FZ-Si sample $(\sim 2 \Omega \cdot \mathrm{cm})$ passivated with $\mathrm{AlO}_{\mathrm{x}}: \mathrm{H} / \mathrm{SiN}_{\mathrm{x}}: \mathrm{H}$. The sample was etched to $\sim 180 \mu \mathrm{m}$ before sample processing. The sample underwent LID treatment at $150{ }^{\circ} \mathrm{C}$ and $\sim 1$ sun equivalent illumination for $12 \mathrm{~min}$ before being treated at $80{ }^{\circ} \mathrm{C}$ and $\sim 1$ sun illumination.

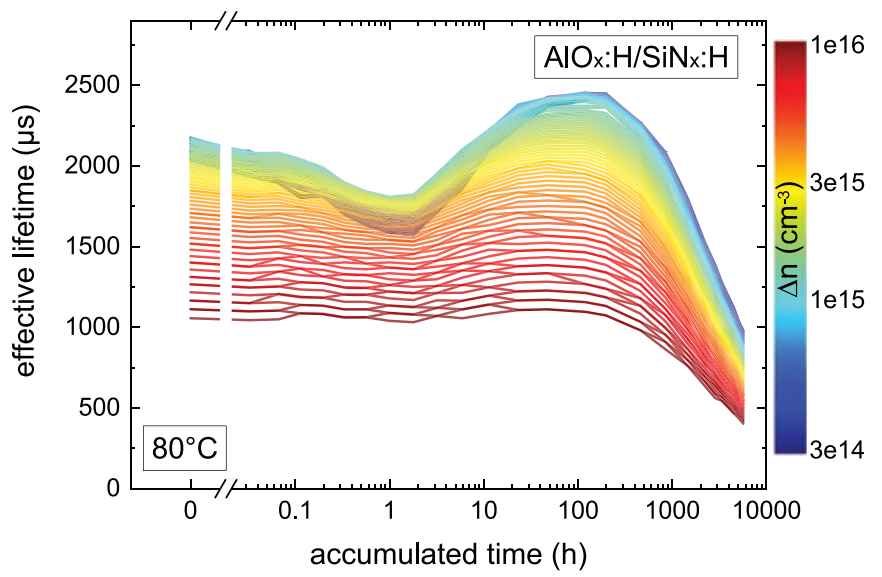

Fig. 9. Injection-resolved evolution of $\tau_{\mathrm{eff}}$ of the B-doped FZ-Si sample shown in Fig. 8.

vation quality has been observed in $\mathrm{AlO}_{\mathrm{x}}: \mathrm{H} / \mathrm{SiN}_{\mathrm{x}}: \mathrm{H}$ passivated samples at higher treatment temperatures (data not shown).

\section{Impact on LID Experiments in $\mathrm{Cz}-\mathrm{Si}$ and $\mathrm{mc}-\mathrm{Si}$}

With respect to the pronounced changes in passivation quality of FZ-Si samples, the question naturally arises whether the observed surface degradation also affects other Si materials. Fig. 10 illustrates results from both a B-doped mc-Si and Cz-Si sample passivated with $\mathrm{SiN}_{\mathrm{x}}: \mathrm{H}$. The $\mathrm{Cz}-\mathrm{Si}$ sample was already treated at $150{ }^{\circ} \mathrm{C}$ and $\sim 1$ sun equivalent illumination for $12 \mathrm{~min}$ to regenerate BO-related defects before the treatment shown in Fig. 10 started. Therefore, the sample shows negligible degradation and regeneration of $\tau_{b}$ due to BO-related defects during the first hours of treatment (black data). For long treatment times, a strong decrease of $\tau_{\text {eff }}$ is observed. This decline could easily be interpreted as instability of the regenerated state of the BO-related defect. However, the decline occurs on the same timescale as the surface degradation observed in FZ-Si samples

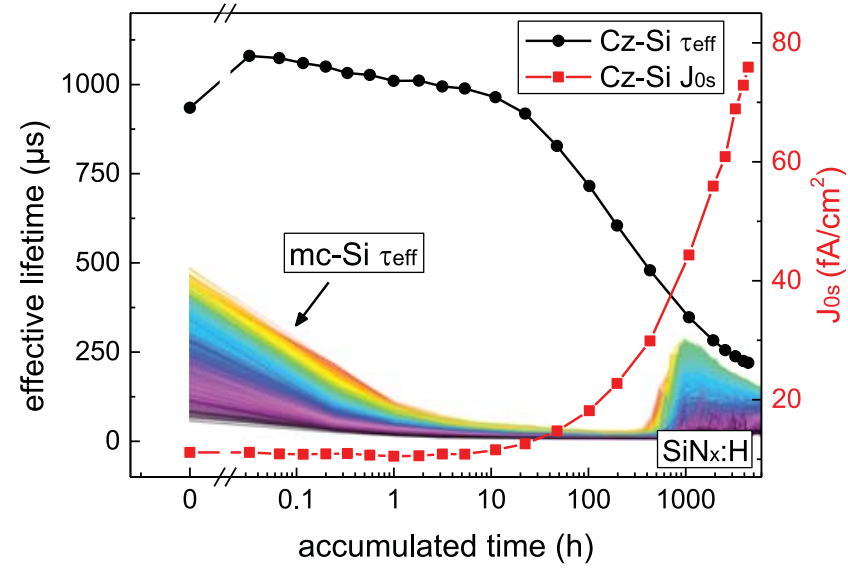

Fig. 10. Single curves: $\tau_{\text {eff }}$ at $\Delta n=2.1 \cdot 10^{15} \mathrm{~cm}^{-3}$ (black) and $J_{0 s}$ (red) of an already BO-regenerated Cz-Si sample (B-doped, $\sim 2 \Omega \cdot \mathrm{cm}, \sim 180 \mu \mathrm{m}$ ) passivated with $\mathrm{SiN}_{\mathrm{x}}: \mathrm{H}$ during $\mathrm{LID}$ treatment at $80^{\circ} \mathrm{C}$ and $\sim 1$ sun equivalent. Color array: Spatially resolved degradation and regeneration of a B-doped mcSi sample $(\sim 1 \Omega \cdot \mathrm{cm}, 180 \mu \mathrm{m})$ treated at $75{ }^{\circ} \mathrm{C}$ and $\sim 1$ sun equivalent. Shown are $\tau_{\text {eff }}$ data from different spots of the sample surface taken with TR-PLI. The data were color coded depending on the initial $\tau_{\text {eff }}$ value, ranging from low (black) to high lifetimes (red). Part of the data is taken from [12]. The injection of the mc-Si sample was estimated to be $\Delta n \approx 2.1 \cdot 10^{15} \mathrm{~cm}^{-3}$ at $250 \mu \mathrm{s}$. Therefore, the $\mathrm{Cz}-\mathrm{Si}$ data are also shown at this $\Delta n$.

and additionally features the same increase of $J_{0 s}$ (red data). Wet chemical repassivation of the sample surface after LID treatment leads to an increase in $\tau_{\text {eff }}$ from $\sim 250 \mu$ s to $\sim 1.5 \mathrm{~ms}$ at $\Delta n \approx 0.1 N_{d}$, verifying that the decrease of $\tau_{\text {eff }}$ is caused by surface-related degradation and that $\tau_{b}$ remains very high even after $\sim 4400 \mathrm{~h}$ of treatment at $80^{\circ} \mathrm{C}$ and $\sim 1$ sun equivalent illumination.

Fig. 10 also shows $\tau_{\text {eff }}$ data of TR-PLI measurements of a mc-Si sample treated at $75{ }^{\circ} \mathrm{C}$ and $\sim 1$ sun equivalent illumination. Each line represents a different spot on the sample surface and lines are color-coded according to the initial $\tau_{\text {eff }}$ value of each spot as further discussed in [12]. In the first $\sim 300 \mathrm{~h}, \tau_{\text {eff }}$ decreases strongly due to LID in the mc-Si bulk. However, when regeneration sets in after $\sim 300 \mathrm{~h}$ of treatment time, it can be seen that $\tau_{\text {eff }}$ does not reach values comparable to the initial values anymore, and after $\sim 1000 \mathrm{~h}$, starts to degrade again.

Comparing the mc-Si $\tau_{\text {eff }}$ data to the $\tau_{\text {eff }}$ values of the regenerated $\mathrm{Cz}-\mathrm{Si}$ sample for times $>1000 \mathrm{~h}$ reveals that this behavior can be explained with a degradation of surface passivation quality: when regeneration of the mc-Si sample sets in, the surface passivation has already degraded significantly and, therefore, even a sample with fully regenerated $\tau_{b}$ cannot achieve the same $\tau_{\text {eff }}$ compared to the initial value before treatment. Wet chemical repassivation of similarly processed mc-Si samples confirms this long-term degradation of surface passivation quality in mc-Si samples and will be discussed in a separate publication.

\section{DISCUSSION}

For all samples shown, time-dependent $J_{0 \mathrm{~s}}$ values were calculated according to the method for the calculation of $J_{0 e}$ described by Kimmerle et al. [18]. Absolute values of $J_{0 s}$ may suffer from some uncertainty when $J_{0 s}$ is very low due to a slight bow in corrected inverse lifetime data. However, it appears that $J_{0 s}$ val- 


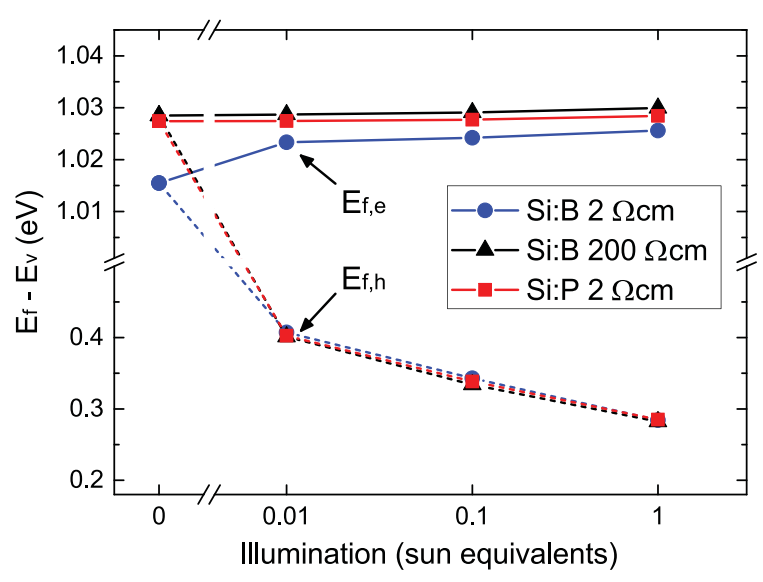

Fig. 11. Simulation of quasi-Fermi levels at the silicon surface at different illumination conditions. Values are given relative to the valence band edge.

ues reflect relative changes in surface passivation quality with good accuracy while only changing slightly during changes of $\tau_{b}$. This makes the calculation of $J_{0 s}$ a promising approach for the separation of changes in the bulk and at the surface in LID studies on lifetime samples.

A strong degradation of surface passivation quality was observed in samples passivated with either $\mathrm{SiN}_{\mathrm{x}}: \mathrm{H}$ or $\mathrm{SiO}_{\mathrm{x}} / \mathrm{SiN}_{\mathrm{x}}: \mathrm{H}$ after prolonged treatment. The comparison of differently doped base material passivated with $\mathrm{SiO}_{\mathrm{x}} / \mathrm{SiN}_{\mathrm{X}}: \mathrm{H}$ revealed differences: A more heavily B-doped sample appears to degrade faster/more pronounced compared to a lightly B-doped or a P-doped sample.

To gain a better understanding of possible degradation mechanisms, samples with different base material but identical surface passivation were simulated using PC1Dmod 6.2.1 [30]. For this purpose, a surface recombination velocity $S_{n}=S_{p}=$ $250 \mathrm{~cm} / \mathrm{s}$ and a fixed charge density of $Q_{f}=+5 \cdot 10^{11} q \mathrm{~cm}^{-2}$ were assumed for all samples. These values correspond to $J_{0 s} \sim 5 \mathrm{fA} / \mathrm{cm}^{2}$ in the P-doped sample, according to [16], which closely resembles the initial value in Fig. 7.

The positive fixed charge density enforces an n-type inversion layer at the surface of p-type substrates while it results in an n-type accumulation layer in n-type substrates. Therefore, the position of Quasi Fermi levels $E_{f, i}$ at the silicon surface is mostly defined by the amount of fixed charge in the dielectric and does not change significantly when using a different base material as can be seen in Fig. 11. Hence, the carrier concentrations close to the surface are also similar, especially under illumination: At 1 sun equivalent, charge carrier concentrations do not differ by more than $12 \%$ rel. in the simulated samples. According to Fig. 12, the depth of the space charge region is also very similar at stronger illumination. Therefore, a difference in degradation behavior of samples made of different base materials seems to be neither related to different carrier concentrations nor position of $E_{f, i}$ at the silicon surface. Still, the real samples could differ in other parameters besides base doping. Since only three samples with different base material have been investigated here, more experiments are necessary to verify if the observed degradation in surface quality is linked to the substrate doping.

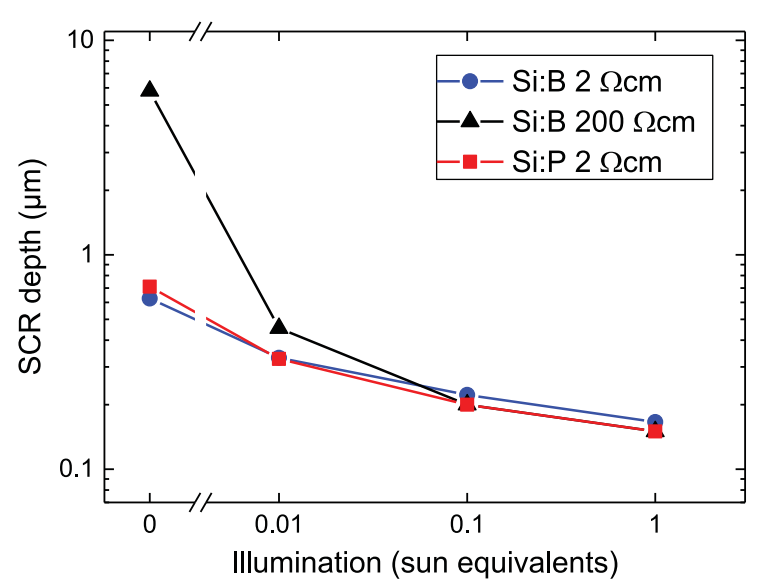

Fig. 12. Simulation of the depth of the space charge region at different illumination conditions.

A similar but much slower surface-related degradation was observed in samples passivated with $\mathrm{AlO}_{\mathrm{x}}: \mathrm{H} / \mathrm{SiN}_{\mathrm{x}}: \mathrm{H}$. Niewelt et al. have reported on samples which show only a slight degradation of this passivation layer stack under similar treatment conditions [31]. This shows that $\mathrm{AlO}_{\mathrm{x}}: \mathrm{H} / \mathrm{SiN}_{\mathrm{x}}: \mathrm{H}$ passivated samples can be, in principle, rather stable. The results shown in Fig. 8, on the other hand, indicate that also $\mathrm{AlO}_{\mathrm{x}}: \mathrm{H} / \mathrm{SiN}_{\mathrm{x}}: \mathrm{H}$ may suffer from a significant degradation of surface passivation quality, even at $80^{\circ} \mathrm{C}$. At $150{ }^{\circ} \mathrm{C}, \mathrm{AlO}_{\mathrm{x}}: \mathrm{H} / \mathrm{SiN}_{\mathrm{x}}: \mathrm{H}$ samples degrade much faster as was observed in [13]. So far, it remains unclear where the difference between rather stable and rather unstable $\mathrm{AlO}_{\mathrm{x}}: \mathrm{H} / \mathrm{SiN}_{\mathrm{x}}: \mathrm{H}$ samples arises from and future research is aimed at clarifying this issue.

However, even the $\mathrm{AlO}_{\mathrm{x}}: \mathrm{H} / \mathrm{SiN}_{\mathrm{x}}: \mathrm{H}$ sample shown in Fig. 8 degrades much slower compared to $\mathrm{SiN}_{\mathrm{X}}: \mathrm{H}$ passivated samples and it can be concluded that an $\mathrm{AlO}_{\mathrm{x}}: \mathrm{H}$ interlayer, while not preventing it entirely, slows down the surface-related degradation significantly. This could be related to a different band structure close to the sample surface: While $\mathrm{SiN}_{\mathrm{x}}: \mathrm{H}$ and $\mathrm{SiO}_{\mathrm{x}} / \mathrm{SiN}_{\mathrm{x}}: \mathrm{H}$ layers attract electrons due to positive layer charge as discussed before, $\mathrm{AlO}_{\mathrm{x}}: \mathrm{H} / \mathrm{SiN}_{\mathrm{x}}: \mathrm{H}$ samples feature a high concentration of holes close to the surface due to negative charge of the $\mathrm{AlO}_{\mathrm{x}}: \mathrm{H}$ layer. Likewise, other charged particles, such as hydrogen ions, could accumulate or move away from the surface depending on the sign of fixed charge in the dielectric layers.

A closer investigation of $\mathrm{SiN}_{\mathrm{x}}: \mathrm{H}$ passivated FZ-Si samples revealed that chemical passivation quality decreases significantly for treatment times $>10 \mathrm{~h}$ at $80{ }^{\circ} \mathrm{C}$ and $\sim 1$ sun equivalent illumination whereas the fixed charge density remains rather unchanged (see Fig. 2 and [15]). In all investigated samples, similar types of bonds exist at the silicon surface such as $\mathrm{Si}-\mathrm{O}$, $\mathrm{Si}-\mathrm{Si}$, or $\mathrm{Si}-\mathrm{H}$ bonds. Therefore, the interface defect density $D_{\text {it }}$ could be affected in a similar manner in the differently coated samples in a region close to the interface, e.g., by generation of new dangling bonds.

One possible degradation mechanism might be found in the evolution of hydrogen bonding states. All of the investigated layers feature a hydrogen-rich $\mathrm{SiN}_{\mathrm{x}}: \mathrm{H}$ layer and received a firing step. It is commonly assumed that the improvement of passivation quality during a firing step is, at least in part, re- 
lated to a hydrogen passivation of interface states [32], [33]. Accordingly, a loss of hydrogen at higher annealing temperatures as suggested in [34]-[36] or a reconfiguration of hydrogen bonding states [37], [38] could lead to a decrease in surface passivation quality. Such a hydrogen-based degradation mechanism could also explain why a nonfired sample and an annealed sample show significantly less degradation of surface passivation quality compared to a fired sample as described in [14]. Additionally, hydrogen could be trapped at boron atoms, explaining why material with higher boron doping suffers from a faster or stronger degradation of surface passivation quality. However, if hydrogen loss is causing the degradation, the observed recovery of passivation quality at higher treatment temperatures would then have to be explained without hydrogen and might be related to a rearrangement of (dangling) bonds. The mechanism could also involve the stepwise evolution of hydrogen containing defects (e.g., hydrogen platelets [39], [40]) which may have formed during cool-down of the deposition or firing step in a region close to the surface. In general, further research has to be conducted to clarify whether hydrogen actually is involved in the degradation of surface passivation as observed in this study.

Already now it can be stated that degradation of surface passivation quality may significantly influence the outcome and interpretation of LID studies aimed at the investigation of bulk defects. This has been demonstrated on a regenerated $\mathrm{Cz}-\mathrm{Si}$ and a nonregenerated mc-Si sample: After long treatment times, the surface passivation limits $\tau_{\text {eff }}$ in both samples, making it hard to draw conclusions about the long-term evolution of $\tau_{b}$. Therefore, it is strongly advised to check for changes in surface passivation quality when performing LID experiments, e.g., by tracking $J_{0 s}$ values. In general, $\mathrm{AlO}_{\mathrm{x}}: \mathrm{H} / \mathrm{SiN}_{\mathrm{x}}: \mathrm{H}$ appears to be the best choice for long-term experiments on lifetime samples when a stable passivation quality is required.

Since $\mathrm{SiO}_{\mathrm{x}} / \mathrm{SiN}_{\mathrm{x}}: \mathrm{H}$ and $\mathrm{AlO}_{\mathrm{x}}: \mathrm{H} / \mathrm{SiN}_{\mathrm{x}}: \mathrm{H}$ passivation layers are used for rear side passivation of PERC solar cells, too, a similar degradation might occur on cell level as well. $\mathrm{AlO}_{\mathrm{x}}: \mathrm{H} / \mathrm{SiN}_{\mathrm{x}}: \mathrm{H}$ passivated samples treated at $60{ }^{\circ} \mathrm{C}$ and 0.1 equivalent suns (and therefore in a similar temperature and injection range compared to PERC cells) show the onset of surface-related degradation after $>1000 \mathrm{~h}$ of treatment (data not shown). However, the investigated lifetime samples were neither separated from ambient air nor metalized, and it is unclear yet whether a similar degradation might affect the rear side passivation of real PERC solar cells, too.

\section{CONCLUSION}

Lifetime samples are often passivated with pure $\mathrm{SiN}_{\mathrm{x}}: \mathrm{H}$ layers. It was observed that this passivation method can be prone to a severe degradation of surface passivation quality during LID treatments, followed by a recovery of surface passivation quality observable at higher treatment temperatures. It was shown that a time-resolved calculation of $J_{0 s}$ is a useful tool to assess the degree of degradation in surface passivation quality, even when changes in $\tau_{b}$ occur simultaneously. The observed degradation can significantly influence the outcome and interpretation of measurement data from LID experiments both in mc-Si as well as in $\mathrm{Cz}-\mathrm{Si}$ as was discussed in detail.

This surface-related degradation is not simply avoidable by using other passivation layers: $\mathrm{SiO}_{\mathrm{x}} / \mathrm{SiN}_{\mathrm{x}}: \mathrm{H}$ and $\mathrm{AlO}_{\mathrm{x}}: \mathrm{H} / \mathrm{SiN}_{\mathrm{x}}: \mathrm{H}$ passivated and fired samples may also show a significant degradation and subsequent recovery of surface passivation quality during LID treatments. As these layer stacks are applied for rear surface passivation of PERC cells, it can be suspected that a similar degradation may occur on cell level, too, and thus solar cell efficiency could suffer in the long term even under field conditions. However, the degradation proceeds much slower in $\mathrm{AlO}_{\mathrm{x}}: \mathrm{H} / \mathrm{SiN}_{\mathrm{x}}: \mathrm{H}$ passivated samples, making this layer stack comparably long-term stable.

\section{ACKNOWLEDGMENT}

The authors would like to thank A. Zuschlag from the University of Konstanz and N. Grant as well as J. Murphy from the University of Warwick for wet chemical repassivation of samples using superacids. Also acknowledged are A. Heilemann, L. Mahlstaedt, J. Rinder, F. Mutter, B. Rettenmaier, J. Engelhardt, and S. Joos from the University of Konstanz for technical support. The content is the responsibility of the authors.

\section{REFERENCES}

[1] J. Lindroos and H. Savin, "Review of light-induced degradation in crystalline silicon solar cells," Sol. Energy Mater. Sol. Cells, vol. 147, pp. 115126, 2016.

[2] H. Fischer and W. Pschunder, "Investigation of photon and thermal induced changes in silicon solar cells," in Proc. 10th IEEE Photovolt. Spec. Conf. Rec., Palo Alto, CA, USA, 1974, pp. 404-411.

[3] K. Bothe and J. Schmidt, "Electronically activated boron-oxygen-related recombination centers in crystalline silicon," J. Appl. Phys., vol. 99, 2006, Art. no. 013701.

[4] T. Niewelt, J. Schön, W. Warta, S. W. Glunz, and M. C. Schubert, "Degradation of crystalline silicon due to boron-oxygen defects," IEEE J. Photovolt., vol. 7, no. 1, pp. 383-398, Jan. 2017.

[5] K. Ramspeck et al., "Light induced degradation of rear passivated mcSi solar cells," in Proc. 27th Eur. Photovolt. Sol. Energy Conf. Exhib., Frankfurt, Germany, 2012, pp. 861-865.

[6] F. Fertig, K. Krauß, and S. Rein, "Light-induced degradation of PECVD aluminium oxide passivated silicon solar cells," Phys. Status Solidi RRL, vol. 9, pp. 41-46, 2015

[7] F. Kersten et al., "Degradation of multicrystalline silicon solar cells and modules after illumination at elevated temperature," Sol. Energy Mater. Sol. Cells, vol. 142, pp. 83-86, 2015.

[8] A. W. Blakers, A. Wang, A. M. Milne, J. Zhao, and M. A. Green, “ $22.8 \%$ efficient silicon solar cell,” Appl. Phys. Lett., vol. 55, pp. 1363-1365, 1989.

[9] A. Herguth, G. Schubert, M. Kaes, and G. Hahn, "A new approach to prevent the negative impact of the metastable defect in boron doped $\mathrm{Cz}$ silicon solar cells," in Proc. 3rd World Conf. Photovolt. Energy Convers., Waikoloa, HI, USA, 2006, pp. 940-943.

[10] A. Herguth, G. Schubert, M. Kaes, and G. Hahn, "Investigations on the long time behavior of the metastable boron-oxygen complex in crystalline silicon," Prog. Photovolt., vol. 16, pp. 135-140, 2008.

[11] F. Kersten et al., "Degradation of multicrystalline silicon solar cells and modules after illumination at elevated temperature," Sol. Energy Mater. Sol. Cells, vol. 142, pp. 83-86, 2015.

[12] A. Zuschlag, D. Skorka, and G. Hahn, "Degradation and regeneration in mc-Si after different gettering steps," Prog. Photovolt., vol. 25, pp. 545$552,2017$.

[13] D. Sperber, A. Herguth, and G. Hahn, "Instability of dielectric surface passivation quality at elevated temperature and illumination," Energy Procedia, vol. 92, pp. 211-217, 2016.

[14] D. Sperber, F. Furtwängler, A. Herguth, and G. Hahn, "On the stability of dielectric passivation layers under illumination and temperature treatment," in Proc. 32nd Eur. Photovolt. Sol. Energy Conf. Exhib., Munich, Germany, 2016, pp. 523-526.

[15] D. Sperber, A. Heilemann, A. Herguth, and G. Hahn, "Temperature and light induced changes in bulk and passivation quality of boron-doped float-zone silicon coated with $\mathrm{SiN}_{\mathrm{X}}: \mathrm{H}$,' IEEE J. Photovolt., vol. 7, no. 2, pp. 463-470, Mar. 2017.

[16] K. R. McIntosh and L. E. Black, "On effective surface recombination parameters," J. Appl. Phys., vol. 116, 2014, Art. no. 014503. 
[17] A. Herguth, "On the meaning(fullness) of the intensity unit 'suns' in light induced degradation experiments," Energy Procedia, vol. 124, pp. 53-59, 2017.

[18] A. Kimmerle, J. Greulich, and A. Wolf, "Carrier-diffusion corrected $\mathrm{J}_{0}$-analysis of charge carrier lifetime measurements for increased consistency," Sol. Energy Mater Sol. Cells, vol. 142, pp. 116-122, 2015.

[19] A. L. Blum, J. S. Swirhun, R. A. Sinton, and A. Kimmerle, "An updated analysis to the WCT-120 QSSPC measurement system using advanced device physics," in Proc. 28th Eur. Photovolt. Sol. Energy Conf. Exhib., Paris, France, 2013, pp. 1521-1523.

[20] A. Kimmerle, P. Rothhardt, A. Wolf, and R. A. Sinton, "Increased reliability for $\mathrm{J}_{0}$-analysis by QSSPC," Energy Procedia, vol. 55, pp. 101-106, 2014.

[21] W. Shockley and W. T. Read Jr., "Statistics of the recombinations of holes and electrons," Phys. Rev., vol. 87, pp. 835-842, 1952.

[22] R. N. Hall, "Electron-hole recombination in germanium," Phys. Rev., vol. 87 , p. $387,1952$.

[23] D. Kiliani et al., "Minority charge carrier lifetime mapping of crystalline silicon wafers by time-resolved photoluminescence imaging," J. Appl. Phys., vol. 110, 2011, Art. no. 054508.

[24] D. Kiliani, A. Herguth, G. Micard, J. Ebser, and G. Hahn, "Time-resolved photoluminescence imaging with electronic shuttering using an image intensifier unit," Sol. Energy Mater. Sol. Cells, vol. 106, pp. 55-59, 2012.

[25] J. Bullock et al., "Superacid passivation of crystalline silicon surfaces," ACS Appl. Mater. Interfaces, vol. 8, pp. 24205-24211, 2016.

[26] N. E. Grant et al., "Superacid-treated silicon surfaces: Extending the limit of carrier lifetime for photovoltaic applications," IEEE J. Photovolt., to be published. Doi: 10.1109/JPHOTOV.2017.2751511.

[27] D. Sperber, A. Graf, A. Heilemann, A. Herguth, and G. Hahn, "Bulk and surface instabilities in boron doped float-zone samples during light induced degradation treatments," Energy Procedia, vol. 124, pp. 794-798, 2017.

[28] D. Sperber, A. Herguth, and G. Hahn, "A 3-state defect model for light induced degradation in boron-doped float-zone silicon," Phys. Status Solidi $R R L$, vol. 11, 2017, Art. No. 1600408.

[29] D. Macdonald, J. Tan, and T. Trupke, "Imaging interstitial iron concentrations in boron-doped crystalline silicon using photoluminescence," $J$. Appl. Phys., vol. 103, 2008, Art. no. 073710.

[30] H. Haug and J. Greulich, "PC1Dmod 6.2 - Improved simulation of c$\mathrm{Si}$ devices with updates on device physics and user interface," Energy Procedia, vol. 92, pp. 60-68, 2016.

[31] T. Niewelt, W. Kwapil, M. Selinger, A. Richter, and M. C. Schubert, "Long-term stability of aluminium oxide based surface passivation schemes under illumination at elevated temperatures," IEEE J. Photovolt., vol. 7, no. 5, pp. 1197-1202, Sep. 2017.

[32] J.-F. Lelièvre et al., "Study of the composition of hydrogenated silicon nitride $\mathrm{SiN}_{\mathrm{X}}: \mathrm{H}$ for efficient surface and bulk passivation of silicon," Sol. Energy Mater. Sol. Cells, vol. 93, pp. 1281-1289, 2009.

[33] G. Dingemans, W. Beyer, M. C. M. van de Sanden, and W. M. M. Kessels, "Hydrogen induced passivation of $\mathrm{Si}$ interfaces by $\mathrm{Al}_{2} \mathrm{O}_{3}$ films and $\mathrm{SiO}_{2} / \mathrm{Al}_{2} \mathrm{O}_{3}$ stacks," Appl. Phys. Lett., vol. 97, 2010, Art. no. 152106.

[34] T. C. Kho, K. R. McIntosh, J. T. Tan, A. F. Thomson, and F. W Chen, "Removal of hydrogen and deposition of surface charge during rapid thermal annealing," in Proc. 33rd IEEE Photovolt. Spec. Conf. Rec., San Diego, CA, USA, 2008, pp. 1-5.

[35] T. C. Kho, L. E. Black, and K. R. McIntosh, "Degradation of $\mathrm{Si}_{-} \mathrm{SiO}_{2}$ interfaces during rapid thermal annealing," in Proc. 24th Eur. Photovolt. Sol. Energy Conf. Exhib., Hamburg, Germany, 2009, pp. 1586-1590.

[36] F. W. Chen, J. E. Cotter, A. Cuevas, S. Winderbaum, and K. Roth, "Anomalous thermal behaviour of surface passivation by PECVD silicon nitride on p-type crystalline silicon," in Proc. 20th Eur. Photovolt. Sol. Energy Conf. Exhib., Barcelona, Spain, 2005, pp. 1419-1422.

[37] S. McQuaid, M. J. Binns, R. C. Newman, E. C. Lightowlers, and J. B. Clegg, "Solubility of hydrogen in silicon at $1300{ }^{\circ} \mathrm{C}$," Appl. Phys. Lett., vol. 62, pp. 1612-1614, 1993.

[38] R. Jones, B. J. Coomer, J. P. Goss, B. Hourahine, and A. Resende, "The interaction of hydrogen with deep level defects in silicon," Solid State Phenom., vol. 71, pp. 173-248, 2000.

[39] N. M. Johnson, F. A. Ponce, R. A. Street, and R. J. Nemanich, "Defects in single-crystal silicon induced by hydrogenation," Phys. Rev. B, vol. 35, pp. 4166-4169, 1987.

[40] S. B. Zhang and W. B. Jackson, "Formation of extended hydrogen complexes in silicon," Phys. Rev. B, vol. 43, pp. 12142-12145, 1991. 